\title{
Combining Radiotherapy and Immunotherapy in Lung Cancer: Can We Expect Limitations Due to Altered Normal Tissue Toxicity?
}

\author{
Florian Wirsdörfer, Simone de Leve and Verena Jendrossek * \\ Institute of Cell Biology (Cancer Research), University Hospital Essen, 45147 Essen, Germany; \\ florian.wirsdoerfer@uk-essen.de (F.W.); simone.deleve@uk-essen.de (S.d.L.) \\ * Correspondence: verena.jendrossek@uni-due.de; Tel.: +49-201-723-3380
}

Received: 30 November 2018; Accepted: 19 December 2018; Published: 21 December 2018

check for updates

\begin{abstract}
In recent decades, technical advances in surgery and radiotherapy, as well as breakthroughs in the knowledge on cancer biology, have helped to substantially improve the standard of cancer care with respect to overall response rates, progression-free survival, and the quality of life of cancer patients. In this context, immunotherapy is thought to have revolutionized the standard of care for cancer patients in the long term. For example, immunotherapy approaches such as immune checkpoint blockade are currently increasingly being used in cancer treatment, either alone or in combination with chemotherapy or radiotherapy, and there is hope from the first clinical trials that the appropriate integration of immunotherapy into standard care will raise the success rates of cancer therapy to a new level. Nevertheless, successful cancer therapy remains a major challenge, particularly in tumors with either pronounced resistance to chemotherapy and radiation treatment, a high risk of normal tissue complications, or both, as in lung cancer. Chemotherapy, radiotherapy and immunotherapy have the capacity to evoke adverse effects in normal tissues when administered alone. However, therapy concepts are usually highly complex, and it is still not clear if combining immunotherapy with radio(chemo)therapy will increase the risk of normal tissue complications, in particular since normal tissue toxicity induced by chemotherapy and radiotherapy can involve immunologic processes. Unfortunately, no reliable biomarkers are available so far that are suited to predict the unique normal tissue sensitivity of a given patient to a given treatment. Consequently, clinical trials combining radiotherapy and immunotherapy are attracting major attention, not only regarding efficacy, but also with regard to safety. In the present review, we summarize the current knowledge of radiation-induced and immunotherapy-induced effects in tumor and normal tissue of the lung, and discuss the potential limitations of combined radio-immunotherapy in lung cancer with a focus on the suspected risk for enhanced acute and chronic normal tissue toxicity.
\end{abstract}

Keywords: Irradiation; immune checkpoint inhibition; pneumonitis; fibrosis; T cells; pneumopathy; adverse effects; PD1; PD-L1; CTLA-4

\section{Introduction}

Radiotherapy is part of standard care for cancer patients. More than $60 \%$ of all cancer patients receive radiotherapy alone or in multimodal combinations of surgery, radiotherapy and chemotherapy during the course of their disease, resulting in favorable effects on local tumor regression, long-term survival, and even tumor cure [1-4]. However, treatment outcome still needs to be improved for cancer types with high loco-regional failure rates, a high risk for invasive growth or metastatic spread, or a high risk for normal tissue complications, such as non-small cell lung cancer (NSCLC).

It is widely known that tumor cell intrinsic factors, such as resistance-promoting mutations and tumor cell plasticity, as well as a pronounced tumor heterogeneity, a resistance-promoting 
microenvironment, and the pronounced radiosensitivity of the normal lung tissue, limit the efficacy of radiotherapy to the thoracic region or concurrent platinum-based radiochemotherapy $[5,6]$. Advances in image-guided radiotherapy and the use of novel radiation techniques such as intensity-modulated radiotherapy and proton therapy have improved the accuracy and safety of thoracic radiotherapy [7-9], but the risk for normal tissue complications still limits the application of curative radiation doses to the thoracic region, whereas tolerable doses might be linked to loco-regional failure, despite accepting adverse effects that reduce the quality of life $[10,11]$. Thus, new and biologically optimized strategies for the radiotherapy of lung cancer with acceptable safety profiles and durable responses are needed to overcome these limitations.

In an effort to identify novel and effective treatment strategies to combat cancer, in recent decades, researchers have put a lot of effort into unraveling the principles of the physiological immune response against cancer and the mechanisms of tumor immune escape. These studies revealed, among other things, that an efficient immune response against cancer requires the activation of tumor-specific $\mathrm{CD}^{+} \mathrm{T}$ cells directed against tumor-associated antigens [12,13], and that patients with advanced solid tumors either present tumors with evidence ("hot" immune-sensitive tumors) or without evidence ("cold" immune-resistant tumors) for a T-cell inflamed tumor microenvironment [14,15]. Moreover, it was discovered that, apart from increased production of immunosuppressive mediators such as transforming growth factor beta (TGF- $\beta$ ) or the propagation of regulatory T cells (Treg), tumor cells and immune cells up-regulate specific proteins on their surface, namely cytotoxic T-lymphocyte-associated Protein 4 (CTLA-4), programmed cell death protein 1 (PD1), or indoleamine 2,3-dioxygenase (IDO) on immune cells, and programmed cell death 1 ligand 1 (PD-L1), as well as CTLA-4 and IDO on tumor cells, that enable tumor immune escape in tumors with an initial immune response [16-20]. These findings resulted in the development of several therapeutic strategies aimed at the (re)activation of the antitumor immune responses in cancer patients. Nowadays, immunotherapies, particularly immune checkpoint inhibition (ICI) of CTLA4 and PD1/PDL1, are increasingly used as a promising and effective systemic cancer treatment, boosting the immune response, and thus leading to successful immune recognition and tumor cell killing [21-23]. However, only a fraction of patients is sensitive to ICI treatment (responders), some patients fail to ever respond (innate resistance), and some patients even develop therapy resistance after a short initial response phase (acquired resistance) [24,25]; moreover, patients may suffer from immune-related adverse effects [26]. Thus, further work is necessary to increase the efficacy of immunotherapy by optimal combinations with other immunotherapy approaches, or cytotoxic chemotherapy or radiotherapy.

The use of radiotherapy as a standard treatment option in the therapy of solid human tumors is based on its ability to locally damage cellular macromolecules, particularly DNA. Thereby, exposure to ionizing radiation effectively induces growth arrest and cell death in irradiated tumor cells, resulting in tumor shrinkage and potentially in tumor elimination. However, the discovery that radiation-induced damage to tumor tissues and normal tissues in the radiation field can trigger the activation of the immune system via well-known damage-signaling cascades, immunogenic cell death, or both, has led to a paradigm change in the use of radiotherapy. Preclinical and clinical investigations revealed a complex interplay between radiotherapy, irradiated cells and tissues, and the immune system; for example, exposure to radiotherapy was shown to up-regulate major histocompatibility complex I (MHCI) expression in tumor cells, modulate immunosuppressive barriers in the tumor microenvironment, activate restrictive tumor vessels, trigger the recruitment of immune effector cells to the local tumor, and even elicit systemic tumor-specific immune responses leading to the regression of tumor nodules outside the radiation field (abscopal effects) [27-29]. However, such abscopal responses to radiotherapy alone are only occasionally observed in patients, presumably because the tumor microenvironment efficiently shapes tumor immune escape at multiple levels and thus hampers a beneficial radiation-induced immune activation [30,31]. Because of the limited success of conventional therapies in patients with resistant and metastatic tumors, current clinical studies focus on combining radiotherapy with immunotherapy, particularly ICI, to overcome these limitations and 
harness the combined therapeutic potential of both therapies. The first data of such studies demonstrate that blockade of the PD-1/PD-L1 immune checkpoint improves progression-free survival in a fraction of NSCLC patients with an acceptable safety profile when given after radiotherapy or platinum-based radiochemotherapy [32,33]. Moreover, radiotherapy and CTLA-4 blockade were effective in inducing a systemic anti-tumor T cell response in chemo-refractory metastatic NSCLC that failed to respond to anti-CTLA-4 antibodies alone or in combination with chemotherapy [34]. This study also revealed a rapid expansion of $C D 8^{+} T$ cells recognizing a neoantigen encoded by a radiation-induced gene, thereby pointing to a contribution of radiation-induced exposure of immunogenic factors to the systemic antitumor response.

There is hope that the use of T cell-stimulatory immunotherapies or small-molecule inhibitors of immunosuppressive signaling pathways in the tumor microenvironment in combination with surgery, radiotherapy and/or chemotherapy will revolutionize the success of standard of care for cancer patients in the long term. However, radiotherapy can also up-regulate immunosuppressive signaling cascades in the tumor microenvironment, such as TGF- $\beta$ signaling or expression of PDL1. Moreover, radiation-induced immune activation participates in inflammation-associated normal tissue responses as well as severe, potentially life-threatening acute and chronic inflammatory adverse effects upon thoracic or total body irradiation such as pneumonitis and pulmonary fibrosis [35]. Thus, interfering with the immune system by multiple, consecutive therapeutic interventions with immune activating effects, such as radio(chemo)therapy and immunotherapy, might increase the risk of deregulated and unwanted adverse (auto)immune responses even when given after a temporal gap. For example, a recent case report where radiotherapy was followed by ICI treatment revealed severe inflammatory side effects [36]. The observed inflammatory tissue toxicities suggest potential limitations for combined radio(chemo)therapy and ICI treatment with respect to long-term safety.

Several recent reviews discussed the potential of combining immunotherapy and radiotherapy to treat lung cancer with respect to clinical efficacy [37-45]. Therefore, here we will only briefly summarize the current knowledge of tumor-induced immune escape and the contribution of radiotherapy in modulating tumor immune responses. Instead, we will discuss in more detail potential risks and limitations that may occur when combining radiotherapy and immunotherapy in lung cancer with a focus on the effects of radiation-induced immunomodulation for suppression of efficient anti-tumor immune responses and normal tissue toxicity in the lung.

\section{Radiotherapy in the Thoracic Region-Tumor Control Versus Immune Escape}

Lung cancer currently represents the second most common cancer, as well as the leading cause of death in men and women in the United States (National Cancer Institute, available online: https:/ / seer. cancer.gov) [46]. It is also one of the most common cancers among both men and women in Germany; the 1 st in men ( $25 \%$ of deaths due to cancer), and the 2 nd in women (15\% of deaths due to cancer) (German Centre for Cancer Registry Data, available online: https:/ / www.krebsdaten.de). The majority of cases comprise localized and locally advanced non-small cell lung cancer (NSCLC). Patients are typically treated with surgical resection, radiotherapy and chemotherapy. Stereotactic body radiation therapy (SBRT) is frequently used as an effective treatment in patients with inoperable or early-stage tumors, whereas inoperable patients with locally advanced tumors receive concurrent chemoradiation with conventional fractionated radiotherapy [47-49]. The results and outcomes from clinical trials of the different treatment regimens in lung cancer have been summarized elsewhere [37,49-53]. Thus, we will focus in this part of the review on how exposure to ionizing radiation shapes the immune response towards tumor control and the tumor microenvironment towards immune escape, respectively.

Radiation-induced alterations in the tumor microenvironment involve the direct activation of innate and adaptive immune cells with various effects on tumor growth and tumor cell killing, but also indirect changes in the tumor microenvironment and the tumor vasculature that alter the recruitment and activation state of cells from the innate and adaptive immune system (for a review, see [54-60]). 
Radiotherapy induces damage and cell death in cancer cells, leading to the exposure of immunogenic molecules such as calreticulin on the cell surface [61]. Moreover, damage-associated molecular patterns (DAMPs), such as uric acid, S100 proteins, adenosine triphosphate (ATP) or High-Mobility-Group-Protein B1 (HMGB1), as well as tumor antigens, are released to activate innate and adaptive immune responses [62,63]. In addition, radiation-induced nuclear DNA release and subsequent sensing of cytoplasmic dsDNA can activate the cGMP-AMP synthase (cGAS)-stimulator of interferon genes (STING) pathway, which is closely related to the activation of a type I interferon response with expression of inflammatory genes and the secretion of cytokines that promote antitumor immunity. Uptake of tumor antigens by antigen presenting cells, e.g., dendritic cells, as well as sensing of cancer cell-derived cytoplasmic dsDNA by the cGAS/STING pathway are required for the priming of tumor-specific $T$ cell responses. To trigger the activation of $B$ and $T$ cells, mature dendritic cells migrate to and present antigens in secondary lymphoid organs. Activated T cells and B cells can exert systemic anti-tumor effects by several mechanisms like $\mathrm{CD} 8^{+} \mathrm{T}$ cell mediated cytotoxicity, antibody-dependent cell-mediated cytotoxicity, and antibody-induced complement-mediated lysis [56,61,62,64-68].

A complex interaction between the tumor microenvironment and the immune system is needed to achieve a radiation-induced anti-tumor immunity. Moreover, the induction of tumor antigen-presenting dendritic cells that are essential for $\mathrm{T}$ cell priming largely depends on the radiation dose and fractionation in a tumor-dependent manner. For example, the radiation dose per fraction dictates the level of the exonuclease three prime repair exonuclease 1 (TREX1), which degrades interferon-stimulatory cytosolic dsDNA and thus abrogates the immunogenicity of irradiated cancer cells $[67,69,70]$. Finally, tumor cells exert a range of acquired capabilities to escape the immune system, so that direct anti-tumor immunity in response to radiotherapy alone is a rare event $[30,67,71]$.

Besides radiation-induced anti-tumor immune responses, tumor irradiation can also activate immune cells with tumor-promoting properties. Pro-inflammatory cytokines that are released after radiation-induced tissue damage, as well as the humoral immune response from activated $B$ cells, trigger the recruitment and activation of innate immune cells, such as granulocytes, macrophages and mast cells [72,73]. By releasing several mediators, these innate immune cells can alter gene expression programs, thus favoring pro-survival signaling and cell cycle progression, as well as tissue expansion in tumors [74,75]. Moreover, innate immune cells can release various mediators, which have an impact on fibroblast activation, angiogenesis, and matrix metabolism. Innate immune cells thus have the ability to induce repair, regeneration and tissue remodeling in favor of tumor growth [73,76-78].

Finally, radiation-induced stress or damage in the tumor itself results in several phenotypic changes. By secreting cytokines, chemokines or growth factors, as well as up-regulating specific surface receptors, e.g., PD-L1, CTLA-4, carcinoembryonic antigen-related cell adhesion molecule 1 (CEACAM1), and others, tumor cells become competent in dampening and finally escaping the immune system (Figure 1) [79-84]. Several therapeutic strategies aim at the inhibition of such tumor cell-extrinsic factors that lead to primary and adaptive resistance and will be addressed in more detail in the "Immunotherapy in lung cancer" section, but have also been nicely reviewed by others [24,30].

\section{Radiation-Induced Normal Tissue Toxicity in the Lung}

The lung, with its mucosal barrier, is constantly exposed to foreign particles and pathogens. Therefore, the mucosal barrier is equipped with means to recognize and eliminate any harmful exposures, thereby functioning as an immunological organ. Epithelial cells, alveolar macrophages, and other immune cells in the respiratory tract express pathogen recognition receptors (PRR) to direct powerful immune responses if needed, for example, during infection, leading to immune cell recruitment and inflammation [85]. Besides the recognition of foreign harm, the same PRR can identify endogenous danger signals; the so-called DAMPs.

Despite technological improvements, radiation still directly hits, to some extent, tumor-surrounding healthy tissues during treatment, e.g., the highly radiosensitive lung tissue. Radiation-induced stress, damage or cell death to lung resident cells and local immune cells triggers 
the release of several DAMPs into the extracellular room, immunogenic cell death, or both. Through recognition of these DAMPs via PRR, the radiation-induced damage induces a sterile inflammation in sensitive patients that can evolve into a harmful normal tissue inflammation with life-threatening complications $[86,87]$. It is noteworthy that the damage response from the malignant and healthy tissue residing in the radiation field not only contributes to the local and abscopal effects of radiotherapy against the tumor, but can also induce strong systemic side effects [88-92]. Moreover, as described before, radiation-induced DNA damage and subsequent detection of cytosolic DNA can activate the cGAS/Sting pathway, which is important for the activation of an innate and adaptive antitumor immunity $[93,94]$.

Briefly, the released "danger signals" induce a subsequent chemokine/cytokine secretion, innate and adaptive immune cell recruitment, and activation of recruited immune cells at the site of radiation damage leading to tissue inflammation. This inflammatory response is needed to orchestrate tissue repair and regeneration in order to restore tissue homeostasis. If the inflammation during the acute phase is too excessive, due to overwhelming release of cytokines and reactive oxygen species (ROS), the inflammation can exert toxic effects in the normal tissue (pneumonitis), a severe side effect in patients [95]. Radiation-induced pneumonitis can develop at 4 to 12 weeks after radiotherapy, with symptoms including fever, dry cough, chest pain and dyspnea, or even failure of the respiratory system. The reported occurrence of pneumonitis in lung or breast cancer patients ranges from 13 to $36 \%$ of patients, depending on the diagnosed severity $[34,96]$. Patients suffering from severe radiation-induced pneumonitis are commonly treated with anti-inflammatory corticosteroids, such as prednisone [35,96-99].

Besides radiation-induced acute inflammatory responses, subsequent repair/regeneration processes can manifest as a chronic event, where pathologic immunomodulation and altered microenvironmental changes, e.g., hypoxia, senescence and anti-inflammation, drive excessive tissue remodeling (fibrosis); moreover, exposure to ionizing radiation can also increase the risk for secondary tumor formation on the long-term [57,87,92,100-107]. Radiation-induced lung fibrosis mostly develops 6 to 24 months after radiotherapy, and is characterized by breathing difficulties and subsequent volume loss of the lung [35,108]. The mechanisms of radiation-induced lung disease have been described in detail elsewhere and will not be addressed here $[35,92,106,109]$.

Both the acute and the chronic events of radiation-induced lung disease are accompanied by microenvironmental alterations in the lung tissue, as well as local and systemic immune changes. Current research focuses on the identification of target cells, pathologic signaling molecules and up-stream regulators to develop novel strategies for prevention or treatment against these adverse effects. We speculate that tumor-induced and radiation-induced immune changes in tumor and normal tissues might offer the opportunity to improve immune-mediated tumor killing and to counteract at the same time radiation-induced chronic adverse effects in the lung tissue [110,111].

This is particularly interesting, as the first promising results have recently been obtained using immunotherapy with ICI in combination with radiotherapy for the treatment of NSCLC [32-34]. However, as outlined above, radiotherapy modulates the immune repertoire in tumor tissues and normal lung tissue in various ways. Thus, optimal targeting of the immune system in combination with radiotherapy will require further work to define therapeutic strategies that balance pro-immunogenic and immunosuppressive effects of radiotherapy and outweigh the beneficial effects of radioimmunotherapy between optimal tumor control and normal tissue protection.

\section{Immunotherapy in Lung Cancer}

As mentioned in the sections above, tumors develop intrinsic or radiation-induced alterations that shape an immune phenotype with immunosuppressive or even tumor-promoting characteristics. Major receptors or pathways involved in immunomodulation include vascular endothelial growth factor receptor (VEGFR), epidermal growth factor receptor (EGFR), as well as PD-L1 on tumor cells and the receptors PD1 and CTLA-4 on the site of T cells [112]. However, CTLA-4 expression was also detected 
on multiple tumor cells including NSCLC [19]. Interestingly, a recent study revealed that tumor cell-intrinsic CTLA-4 expression had an impact on the expression of PD-L1, as well as on tumor cell proliferation. Inhibition of CTLA-4 induced the upregulation of PD-L1, as well as the activation of the EGFR pathway in NSCLC cells, highlighting a distinct function of CTLA-4 in tumor cells compared to T cells [113].

Generally, surface expression of the receptors VEGFR and EGFR on tumor cells and their interaction with the corresponding growth factors induces tumor-promoting proliferation, expansion, and malignant conversion of cancer cells, as well as tumor-promoting angiogenesis. VEGF and EGF are commonly released by innate immune cells, but tumor cells can also secrete VEGF in an autocrine manner, thereby stimulating cancer stemness [114-116]. Generally, VEGF is a proangiogenic growth factor and potent inducer of growth and survival of the vascular endothelium. Besides its direct effect on the tumor vasculature, VEGF can also modulate the immune environment [117]. Several studies demonstrated that VEGF has the ability to inhibit the differentiation and function of diverse immune cells like dendritic cells, macrophages, and lymphocytes, respectively [118-120]. More details about the role of VEGF/VEGFR in tumor and immune cells can be found in the following reviews: [121,122]. Activation of EGFR on tumor cells, including NSCLC, also promotes proliferation, invasion, metastasis, anti-apoptotic signaling and angiogenesis in malignant tumors [123-125]. Lung cancer patients have intrinsic or acquire new EGFR mutations during treatment with small-molecule EGFR-inhibitors that complicate current treatment options highlighting the need for the development of novel strategies for EGFR-resistant NSCLC, including combined therapies with ICI or radiotherapy [10,126-129].

In contrast to VEGF and EGF, PD1/PD-L1, as well as CTLA-4 are immune checkpoints that negatively regulate T-cell immune functions, thus indirectly promoting tumor progression via tumor immune escape [130-132]. Our understanding of the mechanisms and pathways how cancers evade and inhibit immune responses and their targeting has largely improved over the years and the state of knowledge has been summarized in recent reviews [23,133-136]. Overall, targeting these structures or pathways with immunotherapies, alone or in combination, substantially improved the care of patients with advanced-stage cancers leading to longer survival rates or even long-lasting tumor remissions. Several of these immunotherapeutic strategies are being evaluated in lung cancer [137-141]. Multiple strategies using either T cell-stimulating agents (tumor necrosis factor receptor (TNFR) superfamily antibodies and peptides, e.g., OX-40), genetically modified T cells (Chimeric Antigen Receptor (CAR)-T cells), bi-specific antibodies, and tumor vaccination or agents that counteract the immunosuppressive tumor microenvironment (e.g., inhibitors of TGF- $\beta$, as well as Toll-like receptor (TLR) agonists) are currently being tested in preclinical and clinical trials [141-150].

So far, two groups of targeted compounds are FDA approved; these include, on the one hand, "targeted antibodies" against the VEGF/VEGFR pathway (Bevacizumab), and the EGFR pathway (Necitumumab), which are being used in a subset of patients with advanced NSCLC [151,152]. Both target the tumor-promoting effects of growth-factor-induced proliferation, expansion and angiogenesis. On the other hand, ICI have been approved by the FDA for cancer treatment, and so far, they have received the most clinical recognition among the current immunotherapeutic agents. ICIs have emerged as a landmark event for the treatment of lung cancer; among the FDA-approved ICIs, Pembrolizumab and Nivolumab (both anti-PD1), as well as Atezolizumab and Durvalumab (both anti-PD-L1), and Ipilimumab (anti-CTLA-4), alone or in combination with each other, were effective against small cell lung cancer (SCLC), NSCLC, and metastatic lung carcinomas, and improved the prognosis in these patients [153-158].

Despite the revolutionary efficacy profile of ICIs, which has raised cancer therapy to a new level, it has to be taken into consideration that unbalancing the immune system with ICI can also generate adverse events with severe complications in patients [159]. These so-called immune-related adverse effects (IRAEs) can occur in the gut, skin, endocrine glands, liver, heart and lung, but can potentially involve any tissue [160-166]. Increasing the knowledge gained over the last years in several trials with ICI has made oncologists aware of the potential risks, but not all variables are yet understood, 
e.g., patient predisposition or pretreatment status of the patient. Several recent reviews highlight the potential risks that could emerge using ICI alone [167-172].

In brief, an ICI-induced immune dysregulation towards an "immune boost" with uncontrolled pro-inflammatory signaling can trigger toxic effects and normal tissue complications. It is already known, e.g., from trauma patients that tissue damage can unbalance the immune system with overwhelming pro-inflammatory responses and the induction of a systemic inflammatory response syndrome (SIRS). Due to this, severe toxic side effects, multiple organ failure, or even death can occur in these patients [173]. Therefore, it is not surprising that ICI can also induce SIRS in cancer patients, including lung cancer [174]. It has to be considered that irradiation also induces tissue damage (trauma) and inflammation with the potential to induce normal tissue toxicity. Similar to trauma patients, the extent of induced tissue-damage in irradiated patients will be critical for the extent of the immune response. Knowing that immunotherapy alone can already induce IRAEs in several tissue types, including the lung, pre- or post-treatment with radio(chemo)therapy might have additive or synergistic life-threating effects in patients that are already fragile in health.

\section{Combining Radiotherapy and Immunotherapy in Lung Cancer}

Several recent reviews have discussed the potential of combining immunotherapy and radiotherapy, including for lung cancer, with respect to clinical efficacy [37-45]. The recent review from Ko et al. published in June 2018 nicely summarizes planned and ongoing trials of combined radioimmunotherapy in patients with NSCLC with respect to present knowledge [37]. Those trials include phase 1 and 2 studies, with disease stages ranging from early stage NSCLC and locally advanced stage NSCLC towards the majority of trials investigating stage IV metastatic NSCLC. Among these trials, all potential settings are under investigation, including the use of different inhibitors and molecules (durvalumab, atezolizumab, pembrolizumab, tremelimumab, nivolumab, ipilimumab, granulocyte-macrophage colony-stimulating factor (GM-CSF), thymosin- $\alpha 1$, as well as virus therapy), different combined inhibitor administrations, and different timing and dosing of radioimmunotherapy. Thus, ongoing clinical trials will add important knowledge and evidence related to this novel and promising combinatory cancer therapy.

The majority of reviews highlight the two comprehensive trials, namely the phase I KEYNOTE-001 trial of pembrolizumab (anti-PD1) in patients with metastatic NSCLC [32] and the phase III PACIFIC trial of durvalumab (anti-PD-L1) in patients with unresectable stage III NSCLC after $\geq 2$ cycles of platinum-based chemoradiation [33].

Both studies have in common that immunotherapy was administered subsequent to radiotherapy. The KEYNOTE-001 trial is a secondary analysis of 97 patients with 24 patients that received thoracic radiotherapy at a median of 11.5 months prior to ICI. Overall pulmonary toxicity was observed in $63 \%$ of all patients that received prior radiotherapy versus $40 \%$ in patients that received no radiotherapy. The incidence of all-grade ICI-related pulmonary toxicities was significantly higher ( $13 \%$ versus $1 \%, p=$ 0.046) in patients with previous radiotherapy treatment. Although significant changes were observed, the study revealed that there are no differences in high-grade $(\geq 3)$ pulmonary toxicities between the radiotherapy and non-radiotherapy group $(4 \%$ versus $1 \%, p=0.44)$.

In the PACIFIC trial, 713 patients were analyzed after sequential ICI treatment starting between 1-42 days after chemoradiation. In the combined radiotherapy/ICI group all-grade pneumonitis was more frequent than in the radiotherapy alone group ( $33.9 \%$ versus $24.8 \%$, no $p$-Value). Nevertheless, the authors reported that the incidence of grade $\geq 3$ pneumonitis was similar in both groups $(3.4 \%$ versus $2.6 \%$, no $p$-value).

Overall, both studies revealed that the risk to develop high-grade pulmonary toxicities is not enhanced when combining radiotherapy and immunotherapy at least with durvalumab and pembrolizumab. What has to be considered is that in the KEYNOTE-001 trial the median interval between radiotherapy and ICI was nearly 1 year. Radiation-induced immunomodulation and pathologic events in normal pulmonary tissues after 1 year are usually described as chronic 
inflammation with profibrotic tissue remodeling. It might thus not be surprising that ICI does not induce high-grade toxicities after that long-time interval.

In contrast, in the PACIFIC trial ICI was given earlier (1-42 day) after radiochemotherapy. In general, radiation-induced acute inflammatory effects are observed in the lungs of treated patients during this timeframe shortly after radiotherapy. Consequently, boosting the immune system with ICI during the acute phase after radiotherapy might bear a higher risk of enhancing all-grade toxicities in the combined treatment group. This was not the case in the PACIFIC trial, and this is potentially linked to the type of ICI used. Since durvalumab mainly targets PD-L1, present on tumor cells, immune-related effects are potentially more likely to be linked to the tumor microenvironment and, to a lesser extent, to the normal tissue. Instead, targeting PD-1 or CTLA-4 on immune cells might enhance the immune response in both the tumor and also the normal tissues, thereby increasing the risk for more frequent or more severe pulmonary toxicities upon combined use with radiotherapy when compared to a combination of radiotherapy with PD-L1-inhibition.

Two recent reviews about the toxicities of treatment with ICI alone corroborate this hypothesis: Pillai and colleagues compared 23 studies, including 5744 patients with NSCLC, in a systematic analysis to investigate potential differences in the toxicities of monotherapies using PD-1 and PD-L1 inhibitors. In fact, the authors revealed that the overall incidence of adverse effects was comparable between the PD-1 and PD-L1 inhibitors ( $64 \%$ versus $66 \%, p=0.8)$, but in patients treated with PD-1 inhibitors IRAEs $(16 \%$ versus $11 \%, p=0.07)$ and pneumonitis ( $4 \%$ versus $2 \%, p=0.01)$ increased compared with patients who received PD-L1 inhibitors [175]. In line with these findings, Khungar and colleagues reported in a systemic analysis including 19 trials, that there was a higher incidence of pneumonitis with the use of PD-1 inhibitors compared with PD-L1 inhibitors in a monotherapy in NSCLC patients [176].

Both the KEYNOTE-001 and the PACIFIC trial show excellent results, as inhibition of PD1 and PD-L1 in combination with radiotherapy significantly increased the objective response rate in patients and significantly extended both the median progression free survival, as well as the median time to death or distant metastasis. However, both trials only tested one potential treatment setting. To fully understand the potential risks of IRAEs that might occur using combined radioimmunotherapy, several further aspects have to be considered, as described below.

One important factor might be the treatment sequence. Should ICI and radiotherapy be given concurrently or sequentially, and does the order of administration have an impact on the outcome? Since radiotherapy of the thoracic region can induce time-dependent changes in the normal lung tissue ranging from pro-inflammatory acute effects towards pro-fibrotic chronic side effects, the different potential treatment settings might also induce distinct effects in the normal lung tissue. Two case reports have revealed that a setting where radiotherapy was given after ICI had beneficial effects. Here, the combination immunotherapy followed by radiotherapy had the capacity to influence tumor responses, overcome resistance to ICI, and even induce abscopal effect with reduced distant metastasis in the lung, at least when using a PD1-inhibitor (Nivolumab) $[177,178]$. Thus, radiotherapy can stimulate immune activation even when immunotherapy has failed.

However, little is known about potential adverse effects in the lung when radiotherapy is delivered together with ICI. Nevertheless, there are single case reports about adverse pulmonary effects upon concomitant use of ICI and radiotherapy. Louvel and colleagues recently reported two patients, both with metastatic melanoma or metastatic colon cancer, where concomitant radiotherapy and PD-1 or PD-L1 blockade induced radiation-pneumonitis [179]. However, the small sample size makes it difficult to draw firm and clear conclusions, and this was also mentioned by the authors. Thus, additional studies are needed to clarify the acute and long-term safety of the different settings of combining radiotherapy and immunotherapy, particularly ICI.

Besides the treatment schedule of ICI plus radiotherapy, the type of inhibitor that is used might also affect the outcome. PD-1 and PD-L1, but also CTLA-4, are differently expressed in tumor cells and in diverse subsets of immune cells. Furthermore, as mentioned above, radiotherapy shapes the 
immune repertoire and tissue microenvironment in the tumor, as well as in the normal tissue, in a time-dependent, dose-dependent, volume-dependent, and tissue-specific manner. For example, in the lung, the appearance of distinct immune cells and their phenotypes differs in the acute versus chronic phase after irradiation $[87,106,111,180,181]$. Thus, modulating the immune response by targeting PD-1, PD-L1 or CTLA-4 in lung cancer might cause varying effects in the normal tissue, depending on the time point (acute versus chronic) of application, especially in a setting where ICI is given after radiotherapy of the thoracic region.

Finally, the patient itself, especially the immune status and the characteristics of the tumor, plays an important role. Besides the need for a better understanding how we can optimally combine radio(chemo)therapy and immunotherapy to best harness the combined potential of both to the benefit of the patient, we also need to focus on the immune characteristics of the individual patient. The improved understanding of cancer biology, as well as the identification of predictive and prognostic biomarkers and of potential therapeutic targets, has supported the development of personalized therapies over recent years [182-185]. Several case reports highlight the diversity of therapeutic responses in different patients, especially when the immune system is involved (individual innate resistance, acquired resistance and normal tissue toxicity). Thus, an individual evaluation of both, the tumor characteristics and the immune status of a given patient and tumor, are required. Furthermore, the diverse therapeutic responses in different patients highlight the importance to develop tools for a reliable prediction of normal tissue toxicity probability in each patient prior to the combined treatment.

Thus, radiotherapy centers should take the opportunity to collect suitable and structured datasets from the current clinical trials including data about adverse effects. The present technology and available tools for radiotherapy-dose-fractionation-volume parameter assessment, together with the available methodology for estimating normal tissue complication probability (NTCP) [186-191] may provide a reliable background for quantitatively detecting "more-than-expected" lung damage, which may be related to the ICI combined administration. Such information can be analyzed according to suspected biological markers to provide suitable hints for prospective trials using radiotherapy and ICI.

\section{Final Remarks}

The current trials combining radiotherapy and immunotherapy show promising results. However, only single possible treatment settings have been tested so far. Moreover, as outlined above, the complex effects of combining irradiation and unbalancing the immune system with ICI are not fully understood, and many open questions remain. Figure 1 provides a schematic overview of the radiation-induced immune changes in tumor and normal tissues. In brief, radiotherapy has the potential to induce stress responses and cell death in cancer cells with subsequent induction of a DC/T cell-driven antitumor immunity. Radiation-induced tissue damage also stimulates the influx of innate immune cells with tumor-promoting potential. These processes are reminiscent of immune changes observed during tumorigenesis, where tumors upregulate a repertoire of cell surface receptors and adaptive changes in the tumor microenvironment to escape $\mathrm{T}$ cell killing and foster immunosuppression and tumor-promoting effects such as angiogenesis.

Immunotherapies were initially developed to cope with the processes involved in tumor immune evasion. ICI interferes with and unbalances the immune response, thereby unleashing an immune boost, at least in a fraction of tumor patients. However, unbalancing the immune response can also induce inflammation-induced toxic side effects in normal tissues. Thus, ICI must be considered a "double-edged sword" that needs careful handling. The same holds true for radiotherapy-induced immune changes; radiotherapy exerts its effects by efficient tumor killing, but it can also damage normal lung tissue. The acute and chronic toxic side effects induced in the radiation-sensitive lung tissue are mediated by a complex interaction between resident lung cells, radiation-induced changes in the lung environment, and cells from the innate and adaptive immune system. Considering that 
radiation-induced lung disease involves time-dependent (acute and chronic) pathologic immune changes in the lung tissue, a combination with ICI might bear the risk of synergistic adverse effects.

Recent clinical trials only represent a small fraction of potential therapeutic settings of combined radiotherapy and immunotherapy. Thus, only additional trials will shed light on the opportunities and risks of combined radioimmunotherapy and will hopefully clarify which of the various potential treatment settings, e.g., (I) concomitant or sequential treatment, (II) chronology of treatment (radiotherapy > ICI, ICI > radiotherapy), (III) the interval between treatments, or (IV) the type of inhibitor used, has the highest probability for an effective and safe treatment of patients with NSCLC.

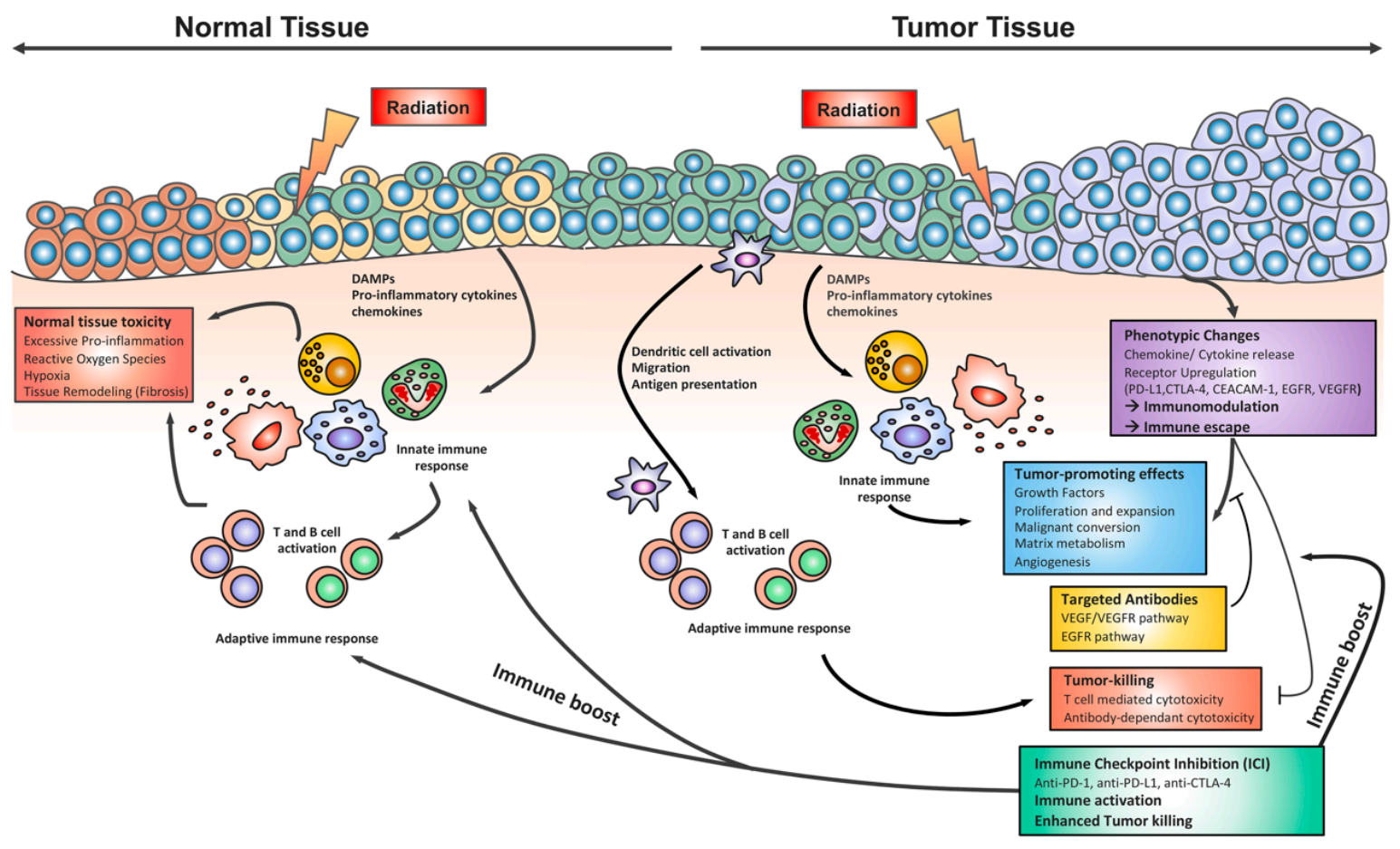

Figure 1. Radiotherapy of malignancies in the thoracic region results in stress, damage and cell death in the tumor tissue, and to some extent also in surrounding normal tissue within the radiation field. The release of damage-associated molecular patterns (DAMPs), cytokines and chemokines leads to the recruitment of immune cells to the site of damage. In the normal lung tissue, the influx of pro-inflammatory immune cells can induce an acute normal tissue-toxicity (pneumonitis) with excessive inflammation, or on the long-term, chronic inflammation, environmental changes and tissue remodeling (fibrosis). In contrast to that, the innate immune system contributes to tumor progression due to tumor-promoting activities. Radiation-induced cell death of tumor cells also results in the release of tumor antigens to activate dendritic cells with subsequent antigen presentation and induction of T cell-mediated tumor killing, a process termed "in situ vaccination". However, several tumor-intrinsic mechanisms shape the innate immune response towards tumor promotion and adaptive immune responses towards immunosuppression, so that the tumor cells escape from $\mathrm{T}$ cell-mediated cytotoxicity. The use of immune checkpoint inhibition (ICI) boosts the immune system, overcoming immunosuppression and immune escape, and thus leading to successful eradication of tumor cells. In normal tissues, ICI might trigger an unbalanced immune activation, thereby potentially enhancing normal tissue toxicity. Combined treatment with ICI and radiotherapy bears the potential risk of synergistic toxic effects, depending on several variables in the treatment setting of radioimmunotherapy.

Author Contributions: F.W., S.d.L. and V.J. equally contributed to the writing of this review article.

Funding: The work was supported by grants of the DFG (GRK1739/2; JE275/1) and the BMBF (ZiSStrans 02NUK047D). 
Acknowledgments: We acknowledge support by the Open Access Publication Fund of the University of Duisburg-Essen.

Conflicts of Interest: The authors declare that the research was conducted in the absence of any commercial or financial relationships that could be construed as a potential conflict of interest.

$\begin{array}{ll}\text { Abbreviations } \\ \text { ATP } & \text { Adenosine triphosphate } \\ \text { CAR } & \text { Chimeric Antigen Receptor } \\ \text { CEACAM-1 } & \text { Carcinoembryonic antigen-related cell adhesion molecule 1 } \\ \text { cGAS } & \text { cGMP-AMP synthase } \\ \text { CTLA-4 } & \text { Cytotoxic T-lymphocyte-associated Protein 4 } \\ \text { DAMPs } & \text { Damage-associated molecular patterns } \\ \text { EGF } & \text { Epidermal growth factor } \\ \text { EGFR } & \text { Epidermal growth factor receptor } \\ \text { GM-CSF } & \text { Granulocyte-macrophage colony-stimulating factor } \\ \text { HMGB1 } & \text { High-Mobility-Group-Protein B1 } \\ \text { ICI } & \text { Immune Checkpoint Inhibition } \\ \text { IRAEs } & \text { Immune-related adverse effects } \\ \text { MHCI } & \text { Major histocompatibility complex I } \\ \text { NSCLC } & \text { Non-small cell lung cancer } \\ \text { NTCP } & \text { Normal tissue complication probability } \\ \text { PD1 } & \text { Programmed cell death protein 1 } \\ \text { PD-L1 } & \text { Programmed cell death 1 ligand 1 } \\ \text { PRR } & \text { Pathogen recognition receptor } \\ \text { ROS } & \text { Reactive oxygen species } \\ \text { RT } & \text { Radiotherapy } \\ \text { SBRT } & \text { Stereotactic body radiotherapy } \\ \text { SCLC } & \text { small cell lung cancer } \\ \text { SIRS } & \text { systemic inflammatory response syndrome } \\ \text { STING } & \text { stimulator of interferon genes } \\ \text { TGF- } \beta & \text { transforming growth factor beta } \\ \text { TNFR } & \text { tumor necrosis factor receptor } \\ \text { TLR } & \text { TOLL-like receptor } \\ \text { TREX1 } & \text { three prime repair exonuclease 1 } \\ \text { VEGF } & \text { Vascular endothelial growth factor } \\ \text { VEGFR } & \text { Vascular endothelial growth factor receptor } \\ & \end{array}$

\section{References}

1. Auperin, A.; Le Pechoux, C.; Rolland, E.; Curran, W.J.; Furuse, K.; Fournel, P.; Belderbos, J.; Clamon, G.; Ulutin, H.C.; Paulus, R.; et al. Meta-analysis of concomitant versus sequential radiochemotherapy in locally advanced non-small-cell lung cancer. J. Clin. Oncol. 2010, 28, 2181-2190. [CrossRef]

2. Crabtree, T.D.; Denlinger, C.E.; Meyers, B.F.; El Naqa, I.; Zoole, J.; Krupnick, A.S.; Kreisel, D.; Patterson, G.A.; Bradley, J.D. Stereotactic body radiation therapy versus surgical resection for stage I non-small cell lung cancer. J. Thorac. Cardiovasc. Surg. 2010, 140, 377-386. [CrossRef]

3. Grills, I.S.; Mangona, V.S.; Welsh, R.; Chmielewski, G.; McInerney, E.; Martin, S.; Wloch, J.; Ye, H.; Kestin, L.L. Outcomes after stereotactic lung radiotherapy or wedge resection for stage I non-small-cell lung cancer. J. Clin. Oncol. 2010, 28, 928-935. [CrossRef]

4. Onishi, H.; Shirato, H.; Nagata, Y.; Hiraoka, M.; Fujino, M.; Gomi, K.; Karasawa, K.; Hayakawa, K.; Niibe, Y.; Takai, Y.; et al. Stereotactic body radiotherapy (SBRT) for operable stage I non-small-cell lung cancer: Can SBRT be comparable to surgery? Int. J. Radiat. Oncol. Biol. Phys. 2011, 81, 1352-1358. [CrossRef] 
5. Ohri, N. Radiotherapy Dosing for Locally Advanced Non-Small Cell Lung Carcinoma: "MTD" or "ALARA"? Front. Oncol. 2017, 7, 205. [CrossRef] [PubMed]

6. Niyazi, M.; Maihoefer, C.; Krause, M.; Rodel, C.; Budach, W.; Belka, C. Radiotherapy and "new" drugs-new side effects? Radiat. Oncol. 2011, 6, 177. [CrossRef] [PubMed]

7. Shirvani, S.M.; Jiang, J.; Gomez, D.R.; Chang, J.Y.; Buchholz, T.A.; Smith, B.D. Intensity modulated radiotherapy for stage III non-small cell lung cancer in the United States: Predictors of use and association with toxicities. Lung Cancer 2013, 82, 252-259. [CrossRef] [PubMed]

8. Chun, S.G.; Hu, C.; Choy, H.; Komaki, R.U.; Timmerman, R.D.; Schild, S.E.; Bogart, J.A.; Dobelbower, M.C.; Bosch, W.; Galvin, J.M.; et al. Impact of Intensity-Modulated Radiation Therapy Technique for Locally Advanced Non-Small-Cell Lung Cancer: A Secondary Analysis of the NRG Oncology RTOG 0617 Randomized Clinical Trial. J. Clin. Oncol. 2017, 35, 56-62. [CrossRef]

9. Higgins, K.A.; O'Connell, K.; Liu, Y.; Gillespie, T.W.; McDonald, M.W.; Pillai, R.N.; Patel, K.R.; Patel, P.R.; Robinson, C.G.; Simone, C.B., 2nd; et al. National Cancer Database Analysis of Proton Versus Photon Radiation Therapy in Non-Small Cell Lung Cancer. Int. J. Radiat. Oncol. Biol. Phys. 2017, 97, 128-137. [CrossRef]

10. Bradley, J.D.; Paulus, R.; Komaki, R.; Masters, G.; Blumenschein, G.; Schild, S.; Bogart, J.; Hu, C.; Forster, K.; Magliocco, A.; et al. Standard-dose versus high-dose conformal radiotherapy with concurrent and consolidation carboplatin plus paclitaxel with or without cetuximab for patients with stage IIIA or IIIB non-small-cell lung cancer (RTOG 0617): A randomised, two-by-two factorial phase 3 study. Lancet Oncol. 2015, 16, 187-199. [CrossRef]

11. Farr, K.P.; Khalil, A.A.; Knap, M.M.; Moller, D.S.; Grau, C. Development of radiation pneumopathy and generalised radiological changes after radiotherapy are independent negative prognostic factors for survival in non-small cell lung cancer patients. Radiother. Oncol. 2013, 107, 382-388. [CrossRef] [PubMed]

12. Boon, T.; Coulie, P.G.; Van den Eynde, B. Tumor antigens recognized by T cells. Immunol. Today 1997, 18, 267-268. [CrossRef]

13. Karanikas, V.; Colau, D.; Baurain, J.F.; Chiari, R.; Thonnard, J.; Gutierrez-Roelens, I.; Goffinet, C.; Van Schaftingen, E.V.; Weynants, P.; Boon, T.; et al. High frequency of cytolytic T lymphocytes directed against a tumor-specific mutated antigen detectable with HLA tetramers in the blood of a lung carcinoma patient with long survival. Cancer Res. 2001, 61, 3718-3724. [PubMed]

14. Galon, J.; Fridman, W.H.; Pages, F. The adaptive immunologic microenvironment in colorectal cancer: A novel perspective. Cancer Res. 2007, 67, 1883-1886. [CrossRef]

15. Gajewski, T.F. The Next Hurdle in Cancer Immunotherapy: Overcoming the Non-T-Cell-Inflamed Tumor Microenvironment. Semin. Oncol. 2015, 42, 663-671. [CrossRef]

16. Zamanakou, M.; Germenis, A.E.; Karanikas, V. Tumor immune escape mediated by indoleamine 2,3-dioxygenase. Immunol. Lett. 2007, 111, 69-75. [CrossRef] [PubMed]

17. Beatty, G.L.; Gladney, W.L. Immune escape mechanisms as a guide for cancer immunotherapy. Clin. Cancer Res. 2015, 21, 687-692. [CrossRef]

18. Facciabene, A.; Motz, G.T.; Coukos, G. T-regulatory cells: Key players in tumor immune escape and angiogenesis. Cancer Res. 2012, 72, 2162-2171. [CrossRef]

19. Paulsen, E.E.; Kilvaer, T.K.; Rakaee, M.; Richardsen, E.; Hald, S.M.; Andersen, S.; Busund, L.T.; Bremnes, R.M.; Donnem, T. CTLA-4 expression in the non-small cell lung cancer patient tumor microenvironment: Diverging prognostic impact in primary tumors and lymph node metastases. Cancer Immunol. Immunother. 2017, 66, 1449-1461. [CrossRef]

20. Karanikas, V.; Zamanakou, M.; Kerenidi, T.; Dahabreh, J.; Hevas, A.; Nakou, M.; Gourgoulianis, K.I.; Germenis, A.E. Indoleamine 2,3-dioxygenase (IDO) expression in lung cancer. Cancer Biol. Ther. 2007, 6, 1258-1262. [CrossRef]

21. Holmgaard, R.B.; Zamarin, D.; Munn, D.H.; Wolchok, J.D.; Allison, J.P. Indoleamine 2,3-dioxygenase is a critical resistance mechanism in antitumor T cell immunotherapy targeting CTLA-4. J. Exp. Med. 2013, 210, 1389-1402. [CrossRef] 
22. Gubin, M.M.; Zhang, X.; Schuster, H.; Caron, E.; Ward, J.P.; Noguchi, T.; Ivanova, Y.; Hundal, J.; Arthur, C.D.; Krebber, W.J.; et al. Checkpoint blockade cancer immunotherapy targets tumour-specific mutant antigens. Nature 2014, 515, 577-581. [CrossRef] [PubMed]

23. Seidel, J.A.; Otsuka, A.; Kabashima, K. Anti-PD-1 and Anti-CTLA-4 Therapies in Cancer: Mechanisms of Action, Efficacy, and Limitations. Front. Oncol. 2018, 8, 86. [CrossRef] [PubMed]

24. Sharma, P.; Hu-Lieskovan, S.; Wargo, J.A.; Ribas, A. Primary, Adaptive, and Acquired Resistance to Cancer Immunotherapy. Cell 2017, 168, 707-723. [CrossRef] [PubMed]

25. Jenkins, R.W.; Barbie, D.A.; Flaherty, K.T. Mechanisms of resistance to immune checkpoint inhibitors. Br. J. Cancer 2018, 118, 9-16. [CrossRef]

26. Judd, J.; Zibelman, M.; Handorf, E.; O’Neill, J.; Ramamurthy, C.; Bentota, S.; Doyle, J.; Uzzo, R.G.; Bauman, J.; Borghaei, H.; et al. Immune-Related Adverse Events as a Biomarker in Non-Melanoma Patients Treated with Programmed Cell Death 1 Inhibitors. Oncologist 2017, 22, 1232-1237. [CrossRef]

27. Brix, N.; Tiefenthaller, A.; Anders, H.; Belka, C.; Lauber, K. Abscopal, immunological effects of radiotherapy: Narrowing the gap between clinical and preclinical experiences. Immunol. Rev. 2017, 280, 249-279. [CrossRef] [PubMed]

28. Derer, A.; Frey, B.; Fietkau, R.; Gaipl, U.S. Immune-modulating properties of ionizing radiation: Rationale for the treatment of cancer by combination radiotherapy and immune checkpoint inhibitors. Cancer Immunol. Immunother. 2016, 65, 779-786. [CrossRef]

29. Abuodeh, Y.; Venkat, P.; Kim, S. Systematic review of case reports on the abscopal effect. Curr. Probl. Cancer 2016, 40, 25-37. [CrossRef]

30. Wennerberg, E.; Lhuillier, C.; Vanpouille-Box, C.; Pilones, K.A.; Garcia-Martinez, E.; Rudqvist, N.P.; Formenti, S.C.; Demaria, S. Barriers to Radiation-Induced In Situ Tumor Vaccination. Front. Immunol. 2017, 8, 229. [CrossRef]

31. Ngwa, W.; Ouyang, Z. Following the Preclinical Data: Leveraging the Abscopal Effect More Efficaciously. Front. Oncol. 2017, 7, 66. [CrossRef] [PubMed]

32. Shaverdian, N.; Lisberg, A.E.; Bornazyan, K.; Veruttipong, D.; Goldman, J.W.; Formenti, S.C.; Garon, E.B.; Lee, P. Previous radiotherapy and the clinical activity and toxicity of pembrolizumab in the treatment of non-small-cell lung cancer: A secondary analysis of the KEYNOTE-001 phase 1 trial. Lancet Oncol. 2017, 18, 895-903. [CrossRef]

33. Antonia, S.J.; Villegas, A.; Daniel, D.; Vicente, D.; Murakami, S.; Hui, R.; Yokoi, T.; Chiappori, A.; Lee, K.H.; de Wit, M.; et al. Durvalumab after Chemoradiotherapy in Stage III Non-Small-Cell Lung Cancer. N. Engl. J. Med. 2017, 377, 1919-1929. [CrossRef] [PubMed]

34. Formenti, S.C.; Rudqvist, N.P.; Golden, E.; Cooper, B.; Wennerberg, E.; Lhuillier, C.; Vanpouille-Box, C.; Friedman, K.; Ferrari de Andrade, L.; Wucherpfennig, K.W.; et al. Radiotherapy induces responses of lung cancer to CTLA-4 blockade. Nat. Med. 2018. [CrossRef]

35. Graves, P.R.; Siddiqui, F.; Anscher, M.S.; Movsas, B. Radiation pulmonary toxicity: From mechanisms to management. Semin. Radiat. Oncol. 2010, 20, 201-207. [CrossRef]

36. Shibaki, R.; Akamatsu, H.; Fujimoto, M.; Koh, Y.; Yamamoto, N. Nivolumab induced radiation recall pneumonitis after two years of radiotherapy. Ann. Oncol. 2017, 28, 1404-1405. [CrossRef]

37. Ko, E.C.; Raben, D.; Formenti, S.C. The Integration of Radiotherapy with Immunotherapy for the Treatment of Non-Small Cell Lung Cancer. Clin. Cancer Res. 2018. [CrossRef]

38. Bhalla, N.; Brooker, R.; Brada, M. Combining immunotherapy and radiotherapy in lung cancer. J. Thorac. Dis. 2018, 10, S1447-S1460. [CrossRef]

39. Hwang, W.L.; Pike, L.R.G.; Royce, T.J.; Mahal, B.A.; Loeffler, J.S. Safety of combining radiotherapy with immune-checkpoint inhibition. Nat. Rev. Clin. Oncol. 2018, 15, 477-494. [CrossRef]

40. Bockel, S.; Durand, B.; Deutsch, E. Combining radiation therapy and cancer immune therapies: From preclinical findings to clinical applications. Cancer Radiother. 2018, 22, 567-580. [CrossRef]

41. Ko, E.C.; Formenti, S.C. Radiotherapy and checkpoint inhibitors: A winning new combination? Ther. Adv. Med. Oncol. 2018, 10. [CrossRef] [PubMed]

42. Cheng, M.; Durm, G.; Hanna, N.; Einhorn, L.H.; Kong, F.S. Can radiotherapy potentiate the effectiveness of immune checkpoint inhibitors in lung cancer? Future Oncol. 2017, 13, 2503-2505. [CrossRef] [PubMed] 
43. Badiyan, S.N.; Roach, M.C.; Chuong, M.D.; Rice, S.R.; Onyeuku, N.E.; Remick, J.; Chilukuri, S.; Glass, E.; Mohindra, P.; Simone, C.B., 2nd. Combining immunotherapy with radiation therapy in thoracic oncology. J. Thorac. Dis. 2018, 10, S2492-S2507. [CrossRef] [PubMed]

44. Kalbasi, A.; Rengan, R. Clinical experiences of combining immunotherapy and radiation therapy in non-small cell lung cancer: Lessons from melanoma. Transl. Lung Cancer Res. 2017, 6, 169-177. [CrossRef] [PubMed]

45. Patel, S.H.; Rimner, A.; Cohen, R.B. Combining immunotherapy and radiation therapy for small cell lung cancer and thymic tumors. Transl. Lung Cancer Res. 2017, 6, 186-195. [CrossRef]

46. Siegel, R.L.; Miller, K.D.; Jemal, A. Cancer statistics, 2018. CA Cancer J. Clin. 2018, 68, 7-30. [CrossRef]

47. Stanic, S.; Paulus, R.; Timmerman, R.D.; Michalski, J.M.; Barriger, R.B.; Bezjak, A.; Videtic, G.M.; Bradley, J. No clinically significant changes in pulmonary function following stereotactic body radiation therapy for early- stage peripheral non-small cell lung cancer: An analysis of RTOG 0236. Int. J. Radiat. Oncol. Biol. Phys. 2014, 88, 1092-1099. [CrossRef]

48. Timmerman, R.; Paulus, R.; Galvin, J.; Michalski, J.; Straube, W.; Bradley, J.; Fakiris, A.; Bezjak, A.; Videtic, G.; Johnstone, D.; et al. Stereotactic body radiation therapy for inoperable early stage lung cancer. JAMA 2010, 303, 1070-1076. [CrossRef]

49. O'Rourke, N.; Roque, I.F.M.; Farre Bernado, N.; Macbeth, F. Concurrent chemoradiotherapy in non-small cell lung cancer. Cochrane Database Syst. Rev. 2010, CD002140. [CrossRef]

50. Maciejczyk, A.; Skrzypczynska, I.; Janiszewska, M. Lung cancer. Radiotherapy in lung cancer: Actual methods and future trends. Rep. Pract. Oncol. Radiother. 2014, 19, 353-360. [CrossRef]

51. Baker, S.; Dahele, M.; Lagerwaard, F.J.; Senan, S. A critical review of recent developments in radiotherapy for non-small cell lung cancer. Radiat. Oncol. 2016, 11, 115. [CrossRef]

52. Loganadane, G.; Martinetti, F.; Mercier, O.; Krhili, S.; Riet, F.G.; Mbagui, R.; To, H.; Le Pechoux, C.; Levy, A. Stereotactic ablative radiotherapy for early stage non-small cell lung cancer: A critical literature review of predictive factors of relapse. Cancer Treat. Rev. 2016, 50, 240-246. [CrossRef]

53. Walls, G.M.; Hanna, G.G.; Qi, F.; Zhao, S.; Xia, J.; Ansari, M.T.; Landau, D. Predicting Outcomes from Radical Radiotherapy for Non-small Cell Lung Cancer: A Systematic Review of the Existing Literature. Front. Oncol. 2018, 8, 433. [CrossRef] [PubMed]

54. Schaue, D.; McBride, W.H. Opportunities and challenges of radiotherapy for treating cancer. Nat. Rev. Clin. Oncol. 2015, 12, 527-540. [CrossRef] [PubMed]

55. Ma, Y.; Yang, H.; Pitt, J.M.; Kroemer, G.; Zitvogel, L. Therapy-induced microenvironmental changes in cancer. J. Mol. Med. 2016, 94, 497-508. [CrossRef] [PubMed]

56. De Visser, K.E.; Eichten, A.; Coussens, L.M. Paradoxical roles of the immune system during cancer development. Nat. Rev. Cancer 2006, 6, 24-37. [CrossRef] [PubMed]

57. McKelvey, K.J.; Hudson, A.L.; Back, M.; Eade, T.; Diakos, C.I. Radiation, inflammation and the immune response in cancer. Mamm. Genome 2018. [CrossRef] [PubMed]

58. Frey, B.; Ruckert, M.; Deloch, L.; Ruhle, P.F.; Derer, A.; Fietkau, R.; Gaipl, U.S. Immunomodulation by ionizing radiation-impact for design of radio-immunotherapies and for treatment of inflammatory diseases. Immunol. Rev. 2017, 280, 231-248. [CrossRef] [PubMed]

59. Jeong, H.; Bok, S.; Hong, B.J.; Choi, H.S.; Ahn, G.O. Radiation-induced immune responses: Mechanisms and therapeutic perspectives. Blood Res. 2016, 51, 157-163. [CrossRef] [PubMed]

60. Klein, D. The Tumor Vascular Endothelium as Decision Maker in Cancer Therapy. Front. Oncol. $2018,8,367$. [CrossRef]

61. Herrera, F.G.; Bourhis, J.; Coukos, G. Radiotherapy combination opportunities leveraging immunity for the next oncology practice. CA Cancer J. Clin. 2017, 67, 65-85. [CrossRef] [PubMed]

62. Golden, E.B.; Pellicciotta, I.; Demaria, S.; Barcellos-Hoff, M.H.; Formenti, S.C. The convergence of radiation and immunogenic cell death signaling pathways. Front. Oncol. 2012, 2, 88. [CrossRef] [PubMed]

63. Hernandez, C.; Huebener, P.; Schwabe, R.F. Damage-associated molecular patterns in cancer: A double-edged sword. Oncogene 2016, 35, 5931-5941. [CrossRef] [PubMed]

64. Gupta, A.; Probst, H.C.; Vuong, V.; Landshammer, A.; Muth, S.; Yagita, H.; Schwendener, R.; Pruschy, M.; Knuth, A.; van den Broek, M. Radiotherapy promotes tumor-specific effector CD8+ T cells via dendritic cell activation. J. Immunol. 2012, 189, 558-566. [CrossRef] [PubMed]

65. Gajewski, T.F.; Schreiber, H.; Fu, Y.X. Innate and adaptive immune cells in the tumor microenvironment. Nat. Immunol. 2013, 14, 1014-1022. [CrossRef] [PubMed] 
66. Deng, L.; Liang, H.; Xu, M.; Yang, X.; Burnette, B.; Arina, A.; Li, X.D.; Mauceri, H.; Beckett, M.; Darga, T.; et al. STING-Dependent Cytosolic DNA Sensing Promotes Radiation-Induced Type I Interferon-Dependent Antitumor Immunity in Immunogenic Tumors. Immunity 2014, 41, 843-852. [CrossRef] [PubMed]

67. Vanpouille-Box, C.; Alard, A.; Aryankalayil, M.J.; Sarfraz, Y.; Diamond, J.M.; Schneider, R.J.; Inghirami, G.; Coleman, C.N.; Formenti, S.C.; Demaria, S. DNA exonuclease Trex1 regulates radiotherapy-induced tumour immunogenicity. Nat. Commun. 2017, 8, 15618. [CrossRef] [PubMed]

68. Tsou, P.; Katayama, H.; Ostrin, E.J.; Hanash, S.M. The Emerging Role of B Cells in Tumor Immunity. Cancer Res. 2016, 76, 5597-5601. [CrossRef]

69. Diamond, J.M.; Vanpouille-Box, C.; Spada, S.; Rudqvist, N.P.; Chapman, J.R.; Ueberheide, B.M.; Pilones, K.A.; Sarfraz, Y.; Formenti, S.C.; Demaria, S. Exosomes Shuttle TREX1-Sensitive IFN-Stimulatory dsDNA from Irradiated Cancer Cells to DCs. Cancer Immunol. Res. 2018, 6, 910-920. [CrossRef]

70. Vanpouille-Box, C.; Formenti, S.C.; Demaria, S. TREX1 dictates the immune fate of irradiated cancer cells. Oncoimmunology 2017, 6, e1339857. [CrossRef]

71. Vanpouille-Box, C.; Diamond, J.M.; Pilones, K.A.; Zavadil, J.; Babb, J.S.; Formenti, S.C.; Barcellos-Hoff, M.H.; Demaria, S. TGFbeta Is a Master Regulator of Radiation Therapy-Induced Antitumor Immunity. Cancer Res. 2015, 75, 2232-2242. [CrossRef] [PubMed]

72. De Visser, K.E.; Coussens, L.M. The inflammatory tumor microenvironment and its impact on cancer development. Contrib. Microbiol. 2006, 13, 118-137. [CrossRef] [PubMed]

73. De Visser, K.E.; Coussens, L.M. The interplay between innate and adaptive immunity regulates cancer development. Cancer Immunol. Immunother. 2005, 54, 1143-1152. [CrossRef] [PubMed]

74. Barbera-Guillem, E.; May, K.F., Jr.; Nyhus, J.K.; Nelson, M.B. Promotion of tumor invasion by cooperation of granulocytes and macrophages activated by anti-tumor antibodies. Neoplasia 1999, 1, 453-460. [CrossRef] [PubMed]

75. Yuen, G.J.; Demissie, E.; Pillai, S. B lymphocytes and cancer: A love-hate relationship. Trends Cancer 2016, 2, 747-757. [CrossRef] [PubMed]

76. Hagerling, C.; Casbon, A.J.; Werb, Z. Balancing the innate immune system in tumor development. Trends Cell Biol. 2015, 25, 214-220. [CrossRef] [PubMed]

77. Ahn, G.O.; Brown, J.M. Matrix metalloproteinase-9 is required for tumor vasculogenesis but not for angiogenesis: Role of bone marrow-derived myelomonocytic cells. Cancer Cell 2008, 13, 193-205. [CrossRef] [PubMed]

78. Ahn, G.O.; Tseng, D.; Liao, C.H.; Dorie, M.J.; Czechowicz, A.; Brown, J.M. Inhibition of Mac-1 (CD11b/CD18) enhances tumor response to radiation by reducing myeloid cell recruitment. Proc. Natl. Acad. Sci. USA 2010, 107, 8363-8368. [CrossRef]

79. Vinay, D.S.; Ryan, E.P.; Pawelec, G.; Talib, W.H.; Stagg, J.; Elkord, E.; Lichtor, T.; Decker, W.K.; Whelan, R.L.; Kumara, H.; et al. Immune evasion in cancer: Mechanistic basis and therapeutic strategies. Semin. Cancer Biol. 2015, 35, S185-S198. [CrossRef]

80. Gao, Z.W.; Dong, K.; Zhang, H.Z. The roles of CD73 in cancer. BioMed Res. Int. 2014, 2014, 460654. [CrossRef]

81. Qin, A.; Coffey, D.G.; Warren, E.H.; Ramnath, N. Mechanisms of immune evasion and current status of checkpoint inhibitors in non-small cell lung cancer. Cancer Med. 2016, 5, 2567-2578. [CrossRef] [PubMed]

82. Nouvion, A.L.; Beauchemin, N. [CEACAM1 as a central modulator of metabolism, tumor progression, angiogenesis and immunity]. Med. Sci. 2009, 25, 247-252. [CrossRef]

83. Rudqvist, N.P.; Pilones, K.A.; Lhuillier, C.; Wennerberg, E.; Sidhom, J.W.; Emerson, R.O.; Robins, H.S.; Schneck, J.; Formenti, S.C.; Demaria, S. Radiotherapy and CTLA-4 Blockade Shape the TCR Repertoire of Tumor-Infiltrating T Cells. Cancer Immunol. Res. 2018, 6, 139-150. [CrossRef] [PubMed]

84. Lhuillier, C.; Vanpouille-Box, C.; Galluzzi, L.; Formenti, S.C.; Demaria, S. Emerging biomarkers for the combination of radiotherapy and immune checkpoint blockers. Semin. Cancer Biol. 2018, 52, 125-134. [CrossRef] [PubMed]

85. Suzuki, T.; Chow, C.W.; Downey, G.P. Role of innate immune cells and their products in lung immunopathology. Int. J. Biochem. Cell Biol. 2008, 40, 1348-1361. [CrossRef] [PubMed]

86. Ratikan, J.A.; Micewicz, E.D.; Xie, M.W.; Schaue, D. Radiation takes its Toll. Cancer Lett. 2015, 368, $238-245$. [CrossRef] [PubMed]

87. Schaue, D.; Micewicz, E.D.; Ratikan, J.A.; Xie, M.W.; Cheng, G.; McBride, W.H. Radiation and inflammation. Semin. Radiat. Oncol. 2015, 25, 4-10. [CrossRef] [PubMed] 
88. Formenti, S.C.; Demaria, S. Systemic effects of local radiotherapy. Lancet Oncol. 2009, 10, 718-726. [CrossRef]

89. Lumniczky, K.; Safrany, G. The impact of radiation therapy on the antitumor immunity: Local effects and systemic consequences. Cancer Lett. 2015, 356, 114-125. [CrossRef] [PubMed]

90. Mavragani, I.V.; Laskaratou, D.A.; Frey, B.; Candeias, S.M.; Gaipl, U.S.; Lumniczky, K.; Georgakilas, A.G. Key mechanisms involved in ionizing radiation-induced systemic effects. A current review. Toxicol. Res. 2016, 5, 12-33. [CrossRef]

91. Jelonek, K.; Pietrowska, M.; Widlak, P. Systemic effects of ionizing radiation at the proteome and metabolome levels in the blood of cancer patients treated with radiotherapy: The influence of inflammation and radiation toxicity. Int. J. Radiat. Biol. 2017, 93, 683-696. [CrossRef] [PubMed]

92. Wirsdorfer, F.; Jendrossek, V. Modeling DNA damage-induced pneumopathy in mice: Insight from danger signaling cascades. Radiat. Oncol. 2017, 12, 142. [CrossRef] [PubMed]

93. Vanpouille-Box, C.; Demaria, S.; Formenti, S.C.; Galluzzi, L. Cytosolic DNA Sensing in Organismal Tumor Control. Cancer Cell 2018, 34, 361-378. [CrossRef] [PubMed]

94. Chen, Q.; Sun, L.; Chen, Z.J. Regulation and function of the cGAS-STING pathway of cytosolic DNA sensing. Nat. Immunol. 2016, 17, 1142-1149. [CrossRef] [PubMed]

95. Hekim, N.; Cetin, Z.; Nikitaki, Z.; Cort, A.; Saygili, E.I. Radiation triggering immune response and inflammation. Cancer Lett. 2015, 368, 156-163. [CrossRef] [PubMed]

96. Inoue, A.; Kunitoh, H.; Sekine, I.; Sumi, M.; Tokuuye, K.; Saijo, N. Radiation pneumonitis in lung cancer patients: A retrospective study of risk factors and the long-term prognosis. Int. J. Radiat. Oncol. Biol. Phys. 2001, 49, 649-655. [CrossRef]

97. McDonald, S.; Rubin, P.; Phillips, T.L.; Marks, L.B. Injury to the lung from cancer therapy: Clinical syndromes, measurable endpoints, and potential scoring systems. Int. J. Radiat. Oncol. Biol. Phys. 1995, 31, 1187-1203. [CrossRef]

98. Provatopoulou, X.; Athanasiou, E.; Gounaris, A. Predictive markers of radiation pneumonitis. Anticancer Res. 2008, 28, 2421-2432.

99. Giridhar, P.; Mallick, S.; Rath, G.K.; Julka, P.K. Radiation induced lung injury: Prediction, assessment and management. Asian Pac. J. Cancer Prev. 2015, 16, 2613-2617. [CrossRef]

100. Yarnold, J.; Brotons, M.C. Pathogenetic mechanisms in radiation fibrosis. Radiother. Oncol. 2010, 97, $149-161$. [CrossRef]

101. Citrin, D.; Cotrim, A.P.; Hyodo, F.; Baum, B.J.; Krishna, M.C.; Mitchell, J.B. Radioprotectors and mitigators of radiation-induced normal tissue injury. Oncologist 2010, 15, 360-371. [CrossRef] [PubMed]

102. Kim, J.H.; Jenrow, K.A.; Brown, S.L. Mechanisms of radiation-induced normal tissue toxicity and implications for future clinical trials. Radiat. Oncol. J. 2014, 32, 103-115. [CrossRef] [PubMed]

103. Barnett, G.C.; West, C.M.; Dunning, A.M.; Elliott, R.M.; Coles, C.E.; Pharoah, P.D.; Burnet, N.G. Normal tissue reactions to radiotherapy: Towards tailoring treatment dose by genotype. Nat. Rev. Cancer 2009, 9 , 134-142. [CrossRef] [PubMed]

104. Stone, H.B.; Coleman, C.N.; Anscher, M.S.; McBride, W.H. Effects of radiation on normal tissue: Consequences and mechanisms. Lancet Oncol. 2003, 4, 529-536. [CrossRef]

105. Ruhle, A.; Huber, P.E. Normal tissue: Radiosensitivity, toxicity, consequences for planning. Radiologe 2018. [CrossRef]

106. Wirsdorfer, F.; Jendrossek, V. The Role of Lymphocytes in Radiotherapy-Induced Adverse Late Effects in the Lung. Front. Immunol. 2016, 7, 591. [CrossRef]

107. Simone, C.B., 2nd. Thoracic Radiation Normal Tissue Injury. Semin. Radiat. Oncol. 2017, 27, 370-377. [CrossRef]

108. Wynn, T.A.; Ramalingam, T.R. Mechanisms of fibrosis: Therapeutic translation for fibrotic disease. Nat. Med. 2012, 18, 1028-1040. [CrossRef]

109. Tsoutsou, P.G.; Koukourakis, M.I. Radiation pneumonitis and fibrosis: Mechanisms underlying its pathogenesis and implications for future research. Int. J. Radiat. Oncol. Biol. Phys. 2006, 66, 1281-1293. [CrossRef]

110. Wirsdorfer, F.; de Leve, S.; Cappuccini, F.; Eldh, T.; Meyer, A.V.; Gau, E.; Thompson, L.F.; Chen, N.Y.; Karmouty-Quintana, H.; Fischer, U.; et al. Extracellular Adenosine Production by ecto-5'-Nucleotidase (CD73) Enhances Radiation-Induced Lung Fibrosis. Cancer Res. 2016, 76, 3045-3056. [CrossRef] 
111. De Leve, S.; Wirsdorfer, F.; Cappuccini, F.; Schutze, A.; Meyer, A.V.; Rock, K.; Thompson, L.F.; Fischer, J.W.; Stuschke, M.; Jendrossek, V. Loss of CD73 prevents accumulation of alternatively activated macrophages and the formation of prefibrotic macrophage clusters in irradiated lungs. FASEB J. 2017, 31, 2869-2880. [CrossRef] [PubMed]

112. Lanitis, E.; Dangaj, D.; Irving, M.; Coukos, G. Mechanisms regulating T-cell infiltration and activity in solid tumors. Ann. Oncol. 2017, 28, xii18-xii32. [CrossRef] [PubMed]

113. Zhang, H.; Dutta, P.; Liu, J.; Sabri, N.; Song, Y.; Li, W.X.; Li, J. Tumour cell-intrinsic CTLA4 regulates PD-L1 expression in non-small cell lung cancer. J. Cell. Mol. Med. 2018. [CrossRef] [PubMed]

114. Hamerlik, P.; Lathia, J.D.; Rasmussen, R.; Wu, Q.; Bartkova, J.; Lee, M.; Moudry, P.; Bartek, J., Jr.; Fischer, W.; Lukas, J.; et al. Autocrine VEGF-VEGFR2-Neuropilin-1 signaling promotes glioma stem-like cell viability and tumor growth. J. Exp. Med. 2012, 209, 507-520. [CrossRef] [PubMed]

115. O'Sullivan, C.; Lewis, C.E.; Harris, A.L.; McGee, J.O. Secretion of epidermal growth factor by macrophages associated with breast carcinoma. Lancet 1993, 342, 148-149. [CrossRef]

116. Barbera-Guillem, E.; Nyhus, J.K.; Wolford, C.C.; Friece, C.R.; Sampsel, J.W. Vascular endothelial growth factor secretion by tumor-infiltrating macrophages essentially supports tumor angiogenesis, and IgG immune complexes potentiate the process. Cancer Res. 2002, 62, 7042-7049.

117. Mulligan, J.K.; Rosenzweig, S.A.; Young, M.R. Tumor secretion of VEGF induces endothelial cells to suppress T cell functions through the production of PGE2. J. Immunother. 2010, 33, 126-135. [CrossRef]

118. Gabrilovich, D.I.; Chen, H.L.; Girgis, K.R.; Cunningham, H.T.; Meny, G.M.; Nadaf, S.; Kavanaugh, D.; Carbone, D.P. Production of vascular endothelial growth factor by human tumors inhibits the functional maturation of dendritic cells. Nat. Med. 1996, 2, 1096-1103. [CrossRef]

119. Su, J.L.; Yen, C.J.; Chen, P.S.; Chuang, S.E.; Hong, C.C.; Kuo, I.H.; Chen, H.Y.; Hung, M.C.; Kuo, M.L. The role of the VEGF-C/VEGFR-3 axis in cancer progression. Br. J. Cancer 2007, 96, 541-545. [CrossRef]

120. Wada, J.; Suzuki, H.; Fuchino, R.; Yamasaki, A.; Nagai, S.; Yanai, K.; Koga, K.; Nakamura, M.; Tanaka, M.; Morisaki, T.; et al. The contribution of vascular endothelial growth factor to the induction of regulatory T-cells in malignant effusions. Anticancer Res. 2009, 29, 881-888.

121. Li, Y.L.; Zhao, H.; Ren, X.B. Relationship of VEGF/VEGFR with immune and cancer cells: Staggering or forward? Cancer Biol. Med. 2016, 13, 206-214. [CrossRef] [PubMed]

122. Yang, J.; Yan, J.; Liu, B. Targeting VEGF/VEGFR to Modulate Antitumor Immunity. Front. Immunol. 2018, 9, 978. [CrossRef] [PubMed]

123. Engelman, J.A.; Cantley, L.C. The role of the ErbB family members in non-small cell lung cancers sensitive to epidermal growth factor receptor kinase inhibitors. Clin. Cancer Res. 2006, 12, 4372s-4376s. [CrossRef] [PubMed]

124. Fujimoto, N.; Wislez, M.; Zhang, J.; Iwanaga, K.; Dackor, J.; Hanna, A.E.; Kalyankrishna, S.; Cody, D.D.; Price, R.E.; Sato, M.; et al. High expression of ErbB family members and their ligands in lung adenocarcinomas that are sensitive to inhibition of epidermal growth factor receptor. Cancer Res. 2005, 65, 11478-11485. [CrossRef] [PubMed]

125. Minder, P.; Zajac, E.; Quigley, J.P.; Deryugina, E.I. EGFR regulates the development and microarchitecture of intratumoral angiogenic vasculature capable of sustaining cancer cell intravasation. Neoplasia 2015, 17, 634-649. [CrossRef] [PubMed]

126. Zhang, K.; Yuan, Q. Current mechanism of acquired resistance to epidermal growth factor receptor-tyrosine kinase inhibitors and updated therapy strategies in human nonsmall cell lung cancer. J. Cancer Res. Ther. 2016, 12, C131-C137. [CrossRef] [PubMed]

127. Liao, B.C.; Lin, C.C.; Lee, J.H.; Yang, J.C. Optimal management of EGFR-mutant non-small cell lung cancer with disease progression on first-line tyrosine kinase inhibitor therapy. Lung Cancer 2017, 110, 7-13. [CrossRef]

128. Sun, J.M.; Park, K. Can we define the optimal sequence of epidermal growth factor receptor tyrosine kinase inhibitors for the treatment of epidermal growth factor receptor-mutant nonsmall cell lung cancer? Curr. Opin. Oncol. 2017, 29, 89-96. [CrossRef]

129. Moya-Horno, I.; Viteri, S.; Karachaliou, N.; Rosell, R. Combination of immunotherapy with targeted therapies in advanced non-small cell lung cancer (NSCLC). Ther. Adv. Med. Oncol. 2018, 10. [CrossRef]

130. Buchbinder, E.I.; Desai, A. CTLA-4 and PD-1 Pathways: Similarities, Differences, and Implications of Their Inhibition. Am. J. Clin. Oncol. 2016, 39, 98-106. [CrossRef] 
131. Chen, L.; Flies, D.B. Molecular mechanisms of T cell co-stimulation and co-inhibition. Nat. Rev. Immunol. 2013, 13, 227-242. [CrossRef] [PubMed]

132. Pardoll, D.M. The blockade of immune checkpoints in cancer immunotherapy. Nat. Rev. Cancer 2012, 12, 252-264. [CrossRef] [PubMed]

133. Bucktrout, S.L.; Bluestone, J.A.; Ramsdell, F. Recent advances in immunotherapies: From infection and autoimmunity, to cancer, and back again. Genome Med. 2018, 10, 79. [CrossRef] [PubMed]

134. Bianco, A.; Malapelle, U.; Rocco, D.; Perrotta, F.; Mazzarella, G. Targeting immune checkpoints in non small cell lung cancer. Curr. Opin. Pharmacol. 2018, 40, 46-50. [CrossRef] [PubMed]

135. Donini, C.; D’Ambrosio, L.; Grignani, G.; Aglietta, M.; Sangiolo, D. Next generation immune-checkpoints for cancer therapy. J. Thorac. Dis. 2018, 10, S1581-S1601. [CrossRef]

136. De Sousa Linhares, A.; Leitner, J.; Grabmeier-Pfistershammer, K.; Steinberger, P. Not All Immune Checkpoints Are Created Equal. Front. Immunol. 2018, 9, 1909. [CrossRef]

137. Bustamante Alvarez, J.G.; Gonzalez-Cao, M.; Karachaliou, N.; Santarpia, M.; Viteri, S.; Teixido, C.; Rosell, R. Advances in immunotherapy for treatment of lung cancer. Cancer Biol. Med. 2015, 12, 209-222. [CrossRef] [PubMed]

138. Lu, J.; Ramirez, R.A. The Role of Checkpoint Inhibition in Non-Small Cell Lung Cancer. Ochsner J. 2017, 17, 379-387. [PubMed]

139. Malhotra, J.; Jabbour, S.K.; Aisner, J. Current state of immunotherapy for non-small cell lung cancer. Transl. Lung Cancer Res. 2017, 6, 196-211. [CrossRef] [PubMed]

140. Health Quality Ontario. Epidermal Growth Factor Receptor Mutation (EGFR) Testing for Prediction of Response to EGFR-Targeting Tyrosine Kinase Inhibitor (TKI) Drugs in Patients with Advanced Non-Small-Cell Lung Cancer: An Evidence-Based Analysis. Ont. Health Technol. Assess. Ser. 2010, 10, 1-48. [PubMed]

141. Villanueva, N.; Bazhenova, L. New strategies in immunotherapy for lung cancer: Beyond PD-1/PD-L1. Ther. Adv. Respir. Dis. 2018, 12. [CrossRef] [PubMed]

142. Zeltsman, M.; Dozier, J.; McGee, E.; Ngai, D.; Adusumilli, P.S. CAR T-cell therapy for lung cancer and malignant pleural mesothelioma. Transl. Res. 2017, 187, 1-10. [CrossRef]

143. Nemunaitis, J.; Dillman, R.O.; Schwarzenberger, P.O.; Senzer, N.; Cunningham, C.; Cutler, J.; Tong, A.; Kumar, P.; Pappen, B.; Hamilton, C.; et al. Phase II study of belagenpumatucel-L, a transforming growth factor beta-2 antisense gene-modified allogeneic tumor cell vaccine in non-small-cell lung cancer. J. Clin. Oncol. 2006, 24, 4721-4730. [CrossRef]

144. Gough, M.J.; Crittenden, M.R.; Sarff, M.; Pang, P.; Seung, S.K.; Vetto, J.T.; Hu, H.M.; Redmond, W.L.; Holland, J.; Weinberg, A.D. Adjuvant therapy with agonistic antibodies to CD134 (OX40) increases local control after surgical or radiation therapy of cancer in mice. J. Immunother. 2010, 33, 798-809. [CrossRef] [PubMed]

145. Vansteenkiste, J.; Zielinski, M.; Linder, A.; Dahabreh, J.; Gonzalez, E.E.; Malinowski, W.; Lopez-Brea, M.; Vanakesa, T.; Jassem, J.; Kalofonos, H.; et al. Adjuvant MAGE-A3 immunotherapy in resected non-small-cell lung cancer: Phase II randomized study results. J. Clin. Oncol. 2013, 31, 2396-2403. [CrossRef] [PubMed]

146. Li, J.F.; Niu, Y.Y.; Xing, Y.L.; Liu, F. A novel bispecific c-MET/CTLA-4 antibody targeting lung cancer stem cell-like cells with therapeutic potential in human non-small cell lung cancer. Biosci. Rep. 2017. [CrossRef] [PubMed]

147. Krishnamurthy, A.; Jimeno, A. Bispecific antibodies for cancer therapy: A review. Pharmacol. Ther. 2018, 185, 122-134. [CrossRef] [PubMed]

148. Smith, D.A.; Conkling, P.; Richards, D.A.; Nemunaitis, J.J.; Boyd, T.E.; Mita, A.C.; de La Bourdonnaye, G.; Wages, D.; Bexon, A.S. Antitumor activity and safety of combination therapy with the Toll-like receptor 9 agonist IMO-2055, erlotinib, and bevacizumab in advanced or metastatic non-small cell lung cancer patients who have progressed following chemotherapy. Cancer Immunol. Immunother. 2014, 63, 787-796. [CrossRef] [PubMed]

149. Iribarren, K.; Bloy, N.; Buque, A.; Cremer, I.; Eggermont, A.; Fridman, W.H.; Fucikova, J.; Galon, J.; Spisek, R.; Zitvogel, L.; et al. Trial Watch: Immunostimulation with Toll-like receptor agonists in cancer therapy. Oncoimmunology 2016, 5, e1088631. [CrossRef]

150. Zhou, C.; Li, J.; Lin, L.; Shu, R.; Dong, B.; Cao, D.; Li, Q.; Wang, Z. A targeted transforming growth factor-beta (TGF-beta) blocker, TTB, inhibits tumor growth and metastasis. Oncotarget 2018, 9, 23102-23113. [CrossRef] 
151. Russo, A.E.; Priolo, D.; Antonelli, G.; Libra, M.; McCubrey, J.A.; Ferrau, F. Bevacizumab in the treatment of NSCLC: Patient selection and perspectives. Lung Cancer 2017, 8, 259-269. [CrossRef] [PubMed]

152. Thakur, M.K.; Wozniak, A.J. Spotlight on necitumumab in the treatment of non-small-cell lung carcinoma. Lung Cancer 2017, 8, 13-19. [CrossRef] [PubMed]

153. Hellmann, M.D.; Ciuleanu, T.E.; Pluzanski, A.; Lee, J.S.; Otterson, G.A.; Audigier-Valette, C.; Minenza, E.; Linardou, H.; Burgers, S.; Salman, P.; et al. Nivolumab plus Ipilimumab in Lung Cancer with a High Tumor Mutational Burden. N. Engl. J. Med. 2018, 378, 2093-2104. [CrossRef] [PubMed]

154. Tay, R.; Prelaj, A.; Califano, R. Immune checkpoint blockade for advanced non-small cell lung cancer: Challenging clinical scenarios. J. Thorac. Dis. 2018, 10, S1494-S1502. [CrossRef] [PubMed]

155. Ellis, P.M.; Vella, E.T.; Ung, Y.C. Immune Checkpoint Inhibitors for Patients With Advanced Non-Small-Cell Lung Cancer: A Systematic Review. Clin. Lung Cancer 2017, 18, 444-459. [CrossRef] [PubMed]

156. Meyers, D.E.; Bryan, P.M.; Banerji, S.; Morris, D.G. Targeting the PD-1/PD-L1 axis for the treatment of non-small-cell lung cancer. Curr. Oncol. 2018, 25, e324-e334. [CrossRef] [PubMed]

157. Ahmed, K.A.; Kim, S.; Arrington, J.; Naghavi, A.O.; Dilling, T.J.; Creelan, B.C.; Antonia, S.J.; Caudell, J.J.; Harrison, L.B.; Sahebjam, S.; et al. Outcomes targeting the PD-1/PD-L1 axis in conjunction with stereotactic radiation for patients with non-small cell lung cancer brain metastases. J. Neurooncol. 2017, 133, 331-338. [CrossRef] [PubMed]

158. Kumar, R.; Collins, D.; Dolly, S.; McDonald, F.; O’Brien, M.E.R.; Yap, T.A. Targeting the PD-1/PD-L1 axis in non-small cell lung cancer. Curr. Probl. Cancer 2017, 41, 111-124. [CrossRef] [PubMed]

159. Delaunay, M.; Caron, P.; Sibaud, V.; Godillot, C.; Collot, S.; Milia, J.; Prevot, G.; Mazieres, J. Toxicity of immune checkpoints inhibitors. Rev. Mal. Respir. 2018. [CrossRef]

160. Varricchi, G.; Marone, G.; Mercurio, V.; Galdiero, M.R.; Bonaduce, D.; Tocchetti, C.G. Immune Checkpoint Inhibitors and Cardiac Toxicity: An Emerging Issue. Curr. Med. Chem. 2018, 25, 1327-1339. [CrossRef]

161. Byun, D.J.; Wolchok, J.D.; Rosenberg, L.M.; Girotra, M. Cancer immunotherapy-Immune checkpoint blockade and associated endocrinopathies. Nat. Rev. Endocrinol. 2017, 13, 195-207. [CrossRef] [PubMed]

162. Robert, C.; Schachter, J.; Long, G.V.; Arance, A.; Grob, J.J.; Mortier, L.; Daud, A.; Carlino, M.S.; McNeil, C.; Lotem, M.; et al. Pembrolizumab versus Ipilimumab in Advanced Melanoma. N. Engl. J. Med. 2015, 372, 2521-2532. [CrossRef] [PubMed]

163. Johnston, R.L.; Lutzky, J.; Chodhry, A.; Barkin, J.S. Cytotoxic T-lymphocyte-associated antigen 4 antibody-induced colitis and its management with infliximab. Dig. Dis. Sci. 2009, 54, 2538-2540. [CrossRef] [PubMed]

164. Kim, K.W.; Ramaiya, N.H.; Krajewski, K.M.; Jagannathan, J.P.; Tirumani, S.H.; Srivastava, A.; Ibrahim, N. Ipilimumab associated hepatitis: Imaging and clinicopathologic findings. Investig. New Drugs 2013, 31, 1071-1077. [CrossRef] [PubMed]

165. Barjaktarevic, I.Z.; Qadir, N.; Suri, A.; Santamauro, J.T.; Stover, D. Organizing pneumonia as a side effect of ipilimumab treatment of melanoma. Chest 2013, 143, 858-861. [CrossRef] [PubMed]

166. Montani, D.; Seferian, A.; Parent, F.; Humbert, M. Immune checkpoint inhibitor-associated interstitial lung diseases: Some progress but still many issues. Eur. Respir. J. 2017, 50. [CrossRef] [PubMed]

167. Zhang, B.; Wu, Q.; Zhou, Y.L.; Guo, X.; Ge, J.; Fu, J. Immune-related adverse events from combination immunotherapy in cancer patients: A comprehensive meta-analysis of randomized controlled trials. Int. Immunopharmacol. 2018, 63, 292-298. [CrossRef]

168. Michot, J.M.; Bigenwald, C.; Champiat, S.; Collins, M.; Carbonnel, F.; Postel-Vinay, S.; Berdelou, A.; Varga, A.; Bahleda, R.; Hollebecque, A.; et al. Immune-related adverse events with immune checkpoint blockade: A comprehensive review. Eur. J. Cancer 2016, 54, 139-148. [CrossRef]

169. Sandigursky, S.; Mor, A. Immune-Related Adverse Events in Cancer Patients Treated With Immune Checkpoint Inhibitors. Curr. Rheumatol. Rep. 2018, 20, 65. [CrossRef]

170. Simmons, D.; Lang, E. The Most Recent Oncologic Emergency: What Emergency Physicians Need to Know About the Potential Complications of Immune Checkpoint Inhibitors. Cureus 2017, 9, e1774. [CrossRef]

171. Winer, A.; Bodor, J.N.; Borghaei, H. Identifying and managing the adverse effects of immune checkpoint blockade. J. Thorac. Dis. 2018, 10, S480-S489. [CrossRef] [PubMed] 
172. King, G.T.; Sharma, P.; Davis, S.L.; Jimeno, A. Immune and autoimmune-related adverse events associated with immune checkpoint inhibitors in cancer therapy. Drugs Today 2018, 54, 103-122. [CrossRef] [PubMed]

173. Lord, J.M.; Midwinter, M.J.; Chen, Y.F.; Belli, A.; Brohi, K.; Kovacs, E.J.; Koenderman, L.; Kubes, P.; Lilford, R.J. The systemic immune response to trauma: An overview of pathophysiology and treatment. Lancet 2014, 384, 1455-1465. [CrossRef]

174. Sharma, N.; Atluri, P.; Stroud, C.R.G.; Walker, P.R.; Cherukuri, S.D.; Cherry, C.R.; Gibbs, P.; Parent, T.; Hardin, J. Immune related adverse events (irAEs): A unique profile based on tumor type. J. Clin. Oncol. 2017, 35, e14606. [CrossRef]

175. Pillai, R.N.; Behera, M.; Owonikoko, T.K.; Kamphorst, A.O.; Pakkala, S.; Belani, C.P.; Khuri, F.R.; Ahmed, R.; Ramalingam, S.S. Comparison of the toxicity profile of PD-1 versus PD-L1 inhibitors in non-small cell lung cancer: A systematic analysis of the literature. Cancer 2018, 124, 271-277. [CrossRef] [PubMed]

176. Khunger, M.; Rakshit, S.; Pasupuleti, V.; Hernandez, A.V.; Mazzone, P.; Stevenson, J.; Pennell, N.A.; Velcheti, V. Incidence of Pneumonitis With Use of Programmed Death 1 and Programmed Death-Ligand 1 Inhibitors in Non-Small Cell Lung Cancer: A Systematic Review and Meta-Analysis of Trials. Chest 2017, 152, 271-281. [CrossRef] [PubMed]

177. Yuan, Z.; Fromm, A.; Ahmed, K.A.; Grass, G.D.; Yang, G.Q.; Oliver, D.E.; Dilling, T.J.; Antonia, S.J.; Perez, B.A. Radiotherapy Rescue of a Nivolumab-Refractory Immune Response in a Patient with PD-L1-Negative Metastatic Squamous Cell Carcinoma of the Lung. J. Thorac. Oncol. 2017, 12, e135-e136. [CrossRef] [PubMed]

178. Komatsu, T.; Nakamura, K.; Kawase, A. Abscopal Effect of Nivolumab in a Patient with Primary Lung Cancer. J. Thorac. Oncol. 2017, 12, e143-e144. [CrossRef]

179. Louvel, G.; Bahleda, R.; Ammari, S.; Le Pechoux, C.; Levy, A.; Massard, C.; Le Pavec, J.; Champiat, S.; Deutsch, E. Immunotherapy and pulmonary toxicities: Can concomitant immune-checkpoint inhibitors with radiotherapy increase the risk of radiation pneumonitis? Eur. Respir. J. 2018, 51. [CrossRef]

180. Wirsdorfer, F.; Cappuccini, F.; Niazman, M.; de Leve, S.; Westendorf, A.M.; Ludemann, L.; Stuschke, M.; Jendrossek, V. Thorax irradiation triggers a local and systemic accumulation of immunosuppressive CD4+ FoxP3+ regulatory T cells. Radiat. Oncol. 2014, 9, 98. [CrossRef]

181. Kainthola, A.; Haritwal, T.; Tiwari, M.; Gupta, N.; Parvez, S.; Tiwari, M.; Prakash, H.; Agrawala, P.K. Immunological Aspect of Radiation-Induced Pneumonitis, Current Treatment Strategies, and Future Prospects. Front. Immunol. 2017, 8, 506. [CrossRef] [PubMed]

182. Domagala-Kulawik, J.; Raniszewska, A. How to evaluate the immune status of lung cancer patients before immunotherapy. Breathe 2017, 13, 291-296. [CrossRef] [PubMed]

183. Kakimi, K.; Karasaki, T.; Matsushita, H.; Sugie, T. Advances in personalized cancer immunotherapy. Breast Cancer 2017, 24, 16-24. [CrossRef] [PubMed]

184. Kiyotani, K.; Chan, H.T.; Nakamura, Y. Immunopharmacogenomics towards personalized cancer immunotherapy targeting neoantigens. Cancer Sci. 2018, 109, 542-549. [CrossRef] [PubMed]

185. Zappasodi, R.; Wolchok, J.D.; Merghoub, T. Strategies for Predicting Response to Checkpoint Inhibitors. Curr. Hematol. Malig. Rep. 2018, 13, 383-395. [CrossRef] [PubMed]

186. Marks, L.B.; Bentzen, S.M.; Deasy, J.O.; Kong, F.M.; Bradley, J.D.; Vogelius, I.S.; El Naqa, I.; Hubbs, J.L.; Lebesque, J.V.; Timmerman, R.D.; et al. Radiation dose-volume effects in the lung. Int. J. Radiat. Oncol. Biol. Phys. 2010, 76, S70-S76. [CrossRef] [PubMed]

187. Shahzadeh, S.; Gholami, S.; Aghamiri, S.M.R.; Mahani, H.; Nabavi, M.; Kalantari, F. Evaluation of normal lung tissue complication probability in gated and conventional radiotherapy using the 4D XCAT digital phantom. Comput. Biol. Med. 2018, 97, 21-29. [CrossRef]

188. Tekatli, H.; Duijm, M.; Oomen-de Hoop, E.; Verbakel, W.; Schillemans, W.; Slotman, B.J.; Nuyttens, J.J.; Senan, S. Normal Tissue Complication Probability Modeling of Pulmonary Toxicity After Stereotactic and Hypofractionated Radiation Therapy for Central Lung Tumors. Int. J. Radiat. Oncol. Biol. Phys. 2018, 100, 738-747. [CrossRef]

189. Ghita, M.; Dunne, V.L.; McMahon, S.J.; Osman, S.O.; Small, D.M.; Weldon, S.; Taggart, C.C.; McGarry, C.K.; Hounsell, A.R.; Graves, E.E.; et al. Preclinical Evaluation of Dose-Volume Effects and Lung Toxicity Occurring in- and out-of-field. Int. J. Radiat. Oncol. Biol. Phys. 2018. [CrossRef] 
190. Krafft, S.P.; Rao, A.; Stingo, F.; Briere, T.M.; Court, L.E.; Liao, Z.; Martel, M.K. The utility of quantitative CT radiomics features for improved prediction of radiation pneumonitis. Med. Phys. 2018, 45, 5317-5324. [CrossRef]

191. Xiao, L.; Yang, G.; Chen, J.; Yang, Y.; Meng, X.; Wang, X.; Wu, Q.; Huo, Z.; Yu, Q.; Yu, J.; et al. Comparison of predictive powers of functional and anatomic dosimetric parameters for radiation-induced lung toxicity in locally advanced non-small cell lung cancer. Radiother. Oncol. 2018, 129, 242-248. [CrossRef] [PubMed]

(c)

(C) 2018 by the authors. Licensee MDPI, Basel, Switzerland. This article is an open access article distributed under the terms and conditions of the Creative Commons Attribution (CC BY) license (http://creativecommons.org/licenses/by/4.0/). 